\title{
Plant-antivenom: Database of anti-venom medicinal plants
}

\author{
Saulo França Amui ${ }^{1} \cdot$ Renato David Puga $^{2} \cdot$ Andreimar Martins Soares $^{3} \cdot$ Silvana Giuliatti $^{1}$ \\ 1 Department of Genetics, Faculty of Medicine, University of São Paulo, Ribeirão Preto, SP, Brazil \\ 2 Hospital A.C. Camargo, Laboratory of Biotechnology, São Paulo, SP, Brazil \\ 3 Faculty of Pharmaceutical Sciences, University of São Paulo, Ribeirão Preto, SP, Brazil \\ $\triangle$ Corresponding author: silvana@rge.fmrp.usp.br \\ Received June 13, 2010 / Accepted November 18, 2010 \\ Published online: January 15, 2011 \\ (C) 2011 by Pontificia Universidad Católica de Valparaíso, Chile
}

\begin{abstract}
Plant-antivenom is a computational Websystem about medicinal plants with anti-venom properties. The system consists of a database of these plants, including scientific publications on this subject and amino acid sequences of active principles from venomous animals. The system relates these data allowing their integration through different search applications. For the development of the system, the first surveys were conducted in scientific literature, allowing the creation of a publication database in a library for reading and user interaction. Then, classes of categories were created, allowing the use of tags and the organization of content. This database on medicinal plants has information such as family, species, isolated compounds, activity, inhibited animal venoms, among others. Provision is made for submission of new information by registered users, by the use of wiki tools. Content submitted is released in accordance to permission rules defined by the system. The database on biological venom protein amino acid sequences was structured from the essential information from National Center for Biotechnology Information (NCBI). Plant-antivenom's interface is simple, contributing to a fast and functional access to the system and the integration of different data registered on it. Plant-antivenom system is available on the Internet at http://gbi.fmrp.usp.br/plantantivenom.
\end{abstract}

Keywords: animal venoms, natural plant inhibitors, web system

\section{INTRODUCTION}

The development of Web systems that allow storage and intelligent organization of content is an important tool to help search. The motivation for developing the system Plant-antivenom came from the need to relate information about medicinal plants with anti-snake venom activity and venomous animals.

Envenomations by dangerous species of scorpions and snakes constitute a frequent medical emergency and an important public health problem in numerous tropical nations. In developing countries their management is largely inadequate, resulting in high levels of morbidity and mortality. Furthermore, incidence and mortality are not precisely known: scorpion stings are estimated in 1.2 million, resulting in 3,250 yearly fatalities (Chippaux and Goyffon, 2008), and snake bites are thought to fall within a range of 1.2-6 million a year, resulting in 20,000-132,000 fatalities (Chippaux, 1998; Kasturiratne et al. 2008).

Medicinal plants have been used for many years to treat a great variety of diseases including envenomations by animal bites (Martz, 1992; Mors et al. 2000; Soares et al. 2004; Soares et al. 2005; Soares et al. 2009). These plants play a key role in world health, as they are a rich source of many natural inhibitors and pharmacologically active compounds. Many of these substances structurally resemble biological compounds, and this similarity is the basis of their physiological action (Havsteen, 1983). Pharmacological studies have revealed that the extracts and fractions from some of these plants used in traditional medicine are able to antagonize the activity of various crude venoms and 
purified toxins (Borges et al. 2000; Otero et al. 2000; Borges et al. 2001; Biondo et al. 2003; Biondo et al. 2004; Januário et al. 2004; da Silva et al. 2005; Maiorano et al. 2005; Oliveira et al. 2005; Ticli et al. 2005). Medicinal plant extracts have been shown to antagonize the activity of some venoms and toxins. Several plant species are popularly known as anti-snake venom and have been scientifically investigated, such as Eclipta sp., Curcuma longa, Hibiscus esculentus, Casearia sp., Musa paradisiaca, Mucuna pruriens, Bauhinia forficata, Annoma senegallensis, Mikania glomerata, Piper sp., Cordia verbenacea, Pentaclethra macroloba and others (Martz, 1992; Mors et al. 2000; Soares et al. 2004; Soares et al. 2005; Ticli et al. 2005; Diogo et al. 2009). Many active ingredients from snake venoms have been purified. Their molecular structures have been identified and characterized in the most advanced laboratories (Ferreira et al. 1992; Selvanayagam et al. 1996; Abubakar et al. 2000; Batina et al. 2000; Aguiyi et al. 2001; Mahanta and Mukherjee, 2001).

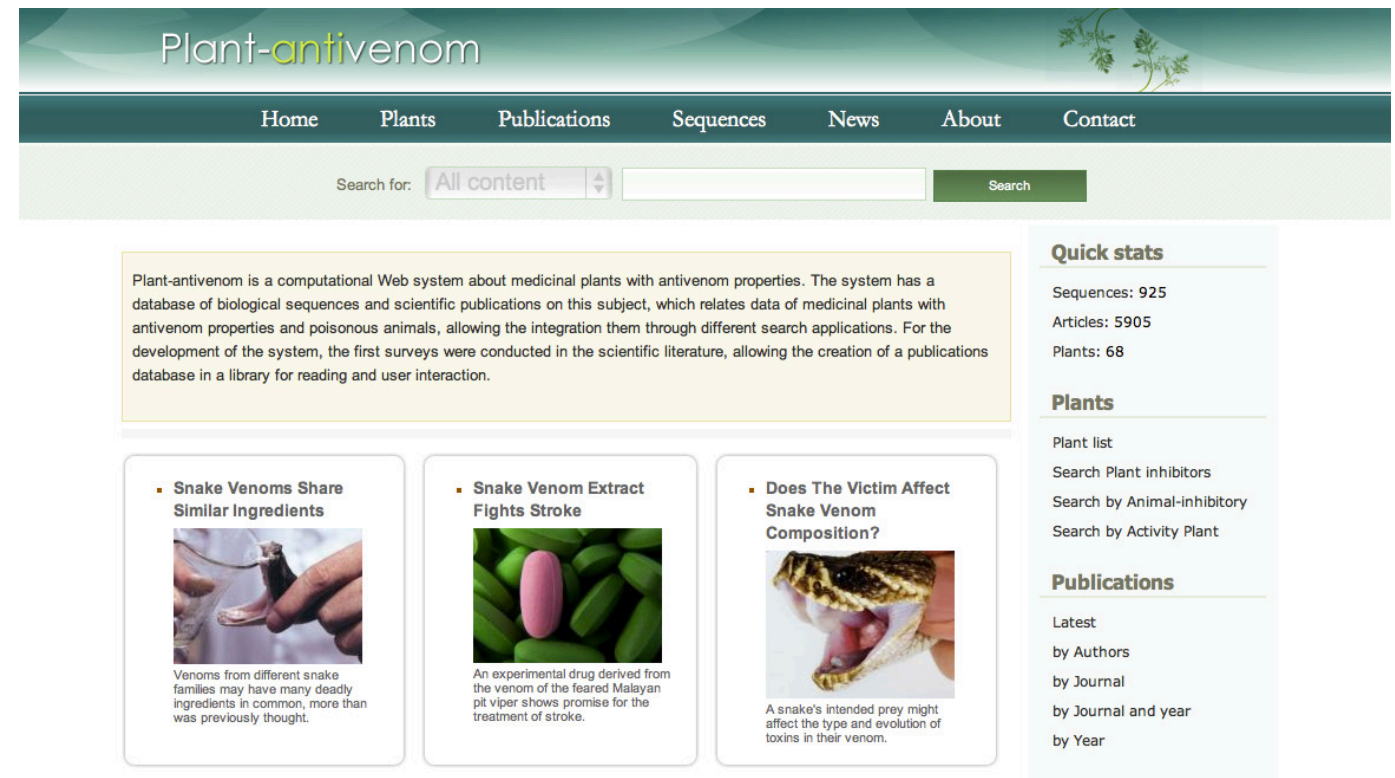

Fig 1. Front page of Plant-antivenom System http://gbi.fmrp.usp.br/plantantivenom.

Increasingly, Web systems have contributed to scientific area with computational tools and specific systems for in silic data analysis, providing fast and reliable results and search schemes. Storing data from medicinal plants with anti-venom properties and venomous animals in a Web system allows the relationship of these data through different search schemes, providing a helpful tool for researchers in this field. The creation of a database was the solution for organizing this information and to promote knowledge on the subject, effectively assisting in the research in this area.

Therefore, the objective of this work was to develop a database of medicinal plants with anti-venom activity, through the storage and the interaction between the information from these plants, including the creation of a repository of scientific publications related to the theme, in addition to list biological sequences of proteins from different classes of venomous animals. In regards to popular data of medicinal plants, the system allows collaborative interaction with users through the use of wiki tools. The whole system was developed in accordance to Web 2.0 standards, containing tools such as ranking, comments, bookmarks, sharing and use of cloud of tags, allowing different forms of research.

\section{MATERIALS AND METHODS}

The Hypertext Preprocessor (PHP) programming language was selected to give dynamism to the system, for being a pre-processing module of the hypertext to Web server, which allows reading and interpretation of PHP code embedded in Web pages. The source code of the inner structure of the portal were obtained through the site http://drupal.org, where there is the free distribution of this 
Content Management System (CMS) written in PHP language, using My Structured Query Language (MySQL) database and Apache server, among others. This was the open source selected for the development and structuring of the proposed portal.

The Drupal in version 5.22 was the content management system selected to manage the site, offering multiple resources and services including administration of users, discussions and comments, and content aggregator, functionality of meta-information using vocabularies focused and publication of Extensible Markup Language (XML) in order to share content, allowing the dynamism of individual publications or users, managed and organized by the system administrator. The system for database management used was MySQL (http://www.mysql.com/), which stores data in tables and performs Structured Query Language (SQL) queries, providing speed and flexibility in searching. This dynamic platform permits attaching other programming languages such as Practical Extraction and Report Language (PERL), (http://www.perl.com/), described as the most popular language for writing scripts Common Gateway Interface (CGI). Additionally to the CMS, other modules were used to create content types and types of data visualization.

The Content Construction Kit (CCK) is the module for building content. This module allows one to specify the type of each field of the content created and allows taxonomy classification of the content into categories and subcategories, permitting multiple lists of categories for classification. With CCK, three different types of content were created in the system: plants, publications and amino acid sequences. The insert form fields were created according to each type of content and its needs. In Publications and Amino Acid Sequences, the contents were automatically entered into the system by importing files in XML format and GenPept, by scripts in Perl, with data obtained from the Pubmed and Protein, both from the National Center for Biotechnology Information (NCBI http://www.ncbi.nlm.nih.gov), respectively. In Plants, the fields of the information on "scientific data" were added manually from scientific literature data, through the reviewing over the subject, also listing their references in the forms of links for browsing. Other information, such as Wiki and Photos are added by users through collaborative wiki tools, and subsequently reviewed by the manager of the database.

All Plant-antivenom contents are ranked for a category term, and this categorization acts directly on search engines by categories available in the system.

The flexibility in the hierarchical organization of categories and the addition of subcategories for most of the content, relating to systems of "nodes", could be conducted through the taxonomy module. In this module, the classes of categories are called "vocabulary", which contains their respective terms, constituting the structure of categories of the Website. With the help of this module, it was possible to insert and list the terms for the various fronts of content such as activity, authors, common name, countries, enzymatic class, family, genus, isolated compounds, keywords, organism, publication, year of publication, animal species, plant species, part of plant used, even allowing to relate them to different types of content available. New terms can be added by the use of tags inserted in the content form, or automatically created by the extraction of terms derived from the XML files and/or GenPept.

To avoid the insertion of false information received by 'spammers' in Wiki content of plants, the Captcha module (Completely Automated Public Turing test to tell Computers and Humans Apart) was used, for testing whether it is a real visitor and to prevent automated spam submissions.

Another module that uses the system terms to customize content visualization is the Views module. Through the terms, it is possible to create several forms of searches. The Views module provides a flexible method for Drupal site designers to control how lists and tables of content are presented. Traditionally, Drupal has hard-coded most of this, particularly in how taxonomy and tracker lists are formatted. Among other things, Views can be used to generate reports, create summaries, and display collections of images and other content.

Collaborative tools have been added through modules capable of promoting interaction between users and contents. The Liquid Wiki Engine Project was the module responsible for promoting collaborative edition of information about plants, allowing the addition of contents from anonymous users in a Wiki format. 
Amui et al.

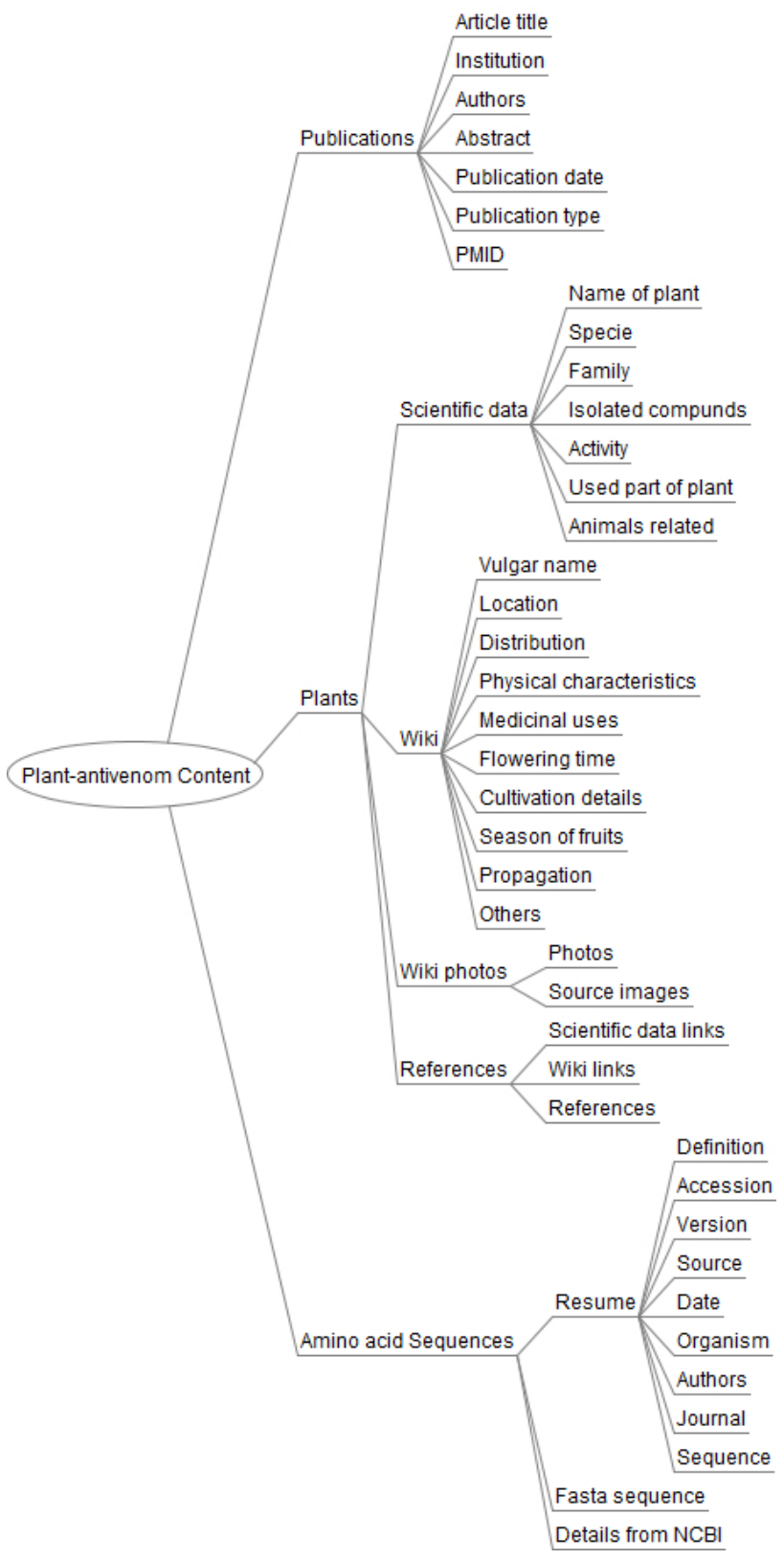

Fig 2. Content of Plant-antivenom System: amino acid sequences, plants, publications and their respective fields.

The Fivestar module was used to promote the voting of contents on plants, publications and amino acid sequences, determining a content classification on the system, valued by the users' opinions. The Comments module allows expression with of opinions written in the form of comments. For the organization and selection of users' preferred contents, the system has uses the Click2bookmark module and Share, which promote the management of bookmarks and its sending through internet tools.

For tables of contents related and located below each page, the Similar entries module was used, a module that displays a block with the most similar nodes to the currently viewed one, based on the title and body fields. 


\section{RESULTS AND DISCUSSION}

\section{Plant-antivenom content}

The Plant-antivenom database has three types of information: medicinal plants with anti-venom properties, amino acid sequences of venom toxins and enzymes on the theme. To compose the plant database the system brings information, such as: scientific data, wiki and references. For scientific data, there are categories as the name of plants, species, family, isolated compounds, activity, part of plant used and related animal venoms. For wiki data, there are fields such as tribal name, location, distribution, physical characteristics, medicinal uses, flowering time, cultivation details, season of fruits, propagation, photos and other information. The references field brings links from scientific data and scientific articles and sources. From the fields presented in the scientific data, all of them were added as tags, allowing the use of filters in the search forms. In addition, the common name and location fields were also added as terms composing the group of categories of such content.

The navigation over the contents in the system can be made by a main horizontal menu or by support links in the right side horizontal block. In the main menu there are links to the plant section, publications, amino acid sequences, and new pages. The side block has mainly Quicklinks from the sections above, which would be links to specific actions, such as "Search Plant Inhibitors" in the box of Plants, or "Search by Authors" on Publications, besides the display of contents related to particular pages.

In the front page, it is possible to view the latest articles, the most viewed articles, the latest plants and amino acid sequences added to the system. Also, it is possible to choose the latest news about this subject, which is revealed in three special boxes at the main page (Figure 1).

To compose the publication database, the system uses information organized by title, institution, authors, abstract, publication date, publication type and PMID (code from Pubmed). Tags such as authors, journal and year were used.

To compose the amino acid sequence database, the system brings information, such as: sequence in FASTA format, details from NCBI and resume, which contains definition, accession, version, source, date, organism, authors, journal and amino acid sequence. The fields used as tags were: Enzymatic class, Genus, Organism, Keywords and Year.

The wiki tools are available only in plant contents. Wikis are generally designed with the philosophy of making it easy to correct mistakes, rather than making it difficult to make them. Thus, while wikis are very open, they provide means to verify the validity of recent additions to the body of pages. The most prominent on almost every wiki is the "Recent Changes" page, a specific list numbering recent edits, or a list of edits made within a given time frame. These wiki pages can filter the list to remove minor edits and edits made by automatic importing scripts ("bots"), with the help of Captcha module. Wiki promotes meaningful topic associations between different pages by making page link creation almost intuitively easy.

A defining characteristic of wiki technology is the ease with which pages can be updated. Wiki fields are open to any user wishing to review and add content about plants. After this kind of contribution, the contents stay in a moderation queue to be examined by the team responsible for database management, which may or may not approve this review, after checking the information and its source. The fields of the "scientific data" are protected and cannot be edited by users in order to preserve the information previously added and reviewed from the scientific literature. The structure of the Plantantivenom system is shown in Figure 2.

The click2bookmark module offers a bookmark feature ('Add to bookmark') for the nodes of a selected content type. As a result, it is possible to get a link 'My bookmarks' in the navigation bar as well as a block listing all the bookmarks.

The Share module hosts the ability to have several ways to share content via widgets and tabs. It is possible to manage hosts of sharing methods and set criteria for when and where to display those methods. Each share method can be displayed as a block, inside the node, or in node links. 
Amui et al.

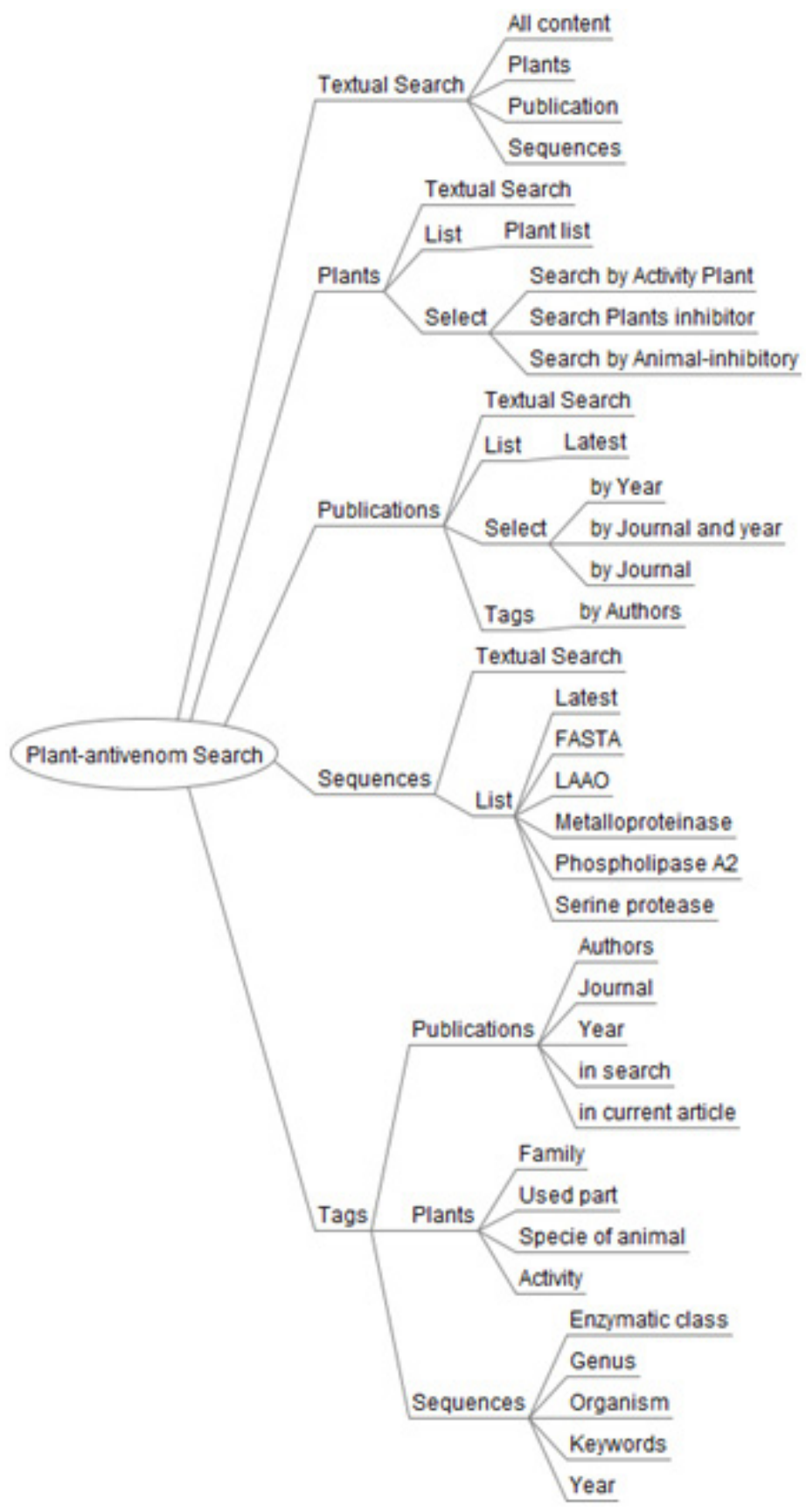

Fig 3. Schema of search: different ways of research in Plant-antivenom.

Users can also express their opinion on a particular content in two ways: by vote or comment. The vote is given by the module "Fivestar" by presenting a numerical average evaluation, while the comments allow free expression that promotes the collaborative nature of the system and the relevant discussions about the exposed contents.

Visitors have access to public data for any type of display. The registered user is allowed to enter data into the system. So, to register in the system, one must complete the online form. After registration, the new user can access the properties of content and send their own popular information on medicinal plants into the system. 


\section{Plant-antivenom search system}

The Plant-antivenom system provides several ways to search for content. Within the system as a whole, it is possible to search through all contents, for plants only, for amino acid sequences and for publications. In plant database, it is possible to find a plant with its name, or with its activity or with the animal venom it can inhibit. The search can be made in multiple ways, interacting all of these items (Figure 3).

The Views module is primarily a tool for site designers who want to customize the presentation of lists of content, such as lists of articles, new content, and content controlled by taxonomy in ways that are not built into Drupal. Views module creates these lists and can present them either as pages, blocks, or both. It can give these pages menu entries, or create them as menu tabs. Views can provide output in a generic list, a table, or lists of teasers. This tool is essentially a smart query builder that, given enough information, can build the proper query, execute it, and display the results. It has four modes, plus a special mode, and provides an impressive amount of functionality from these modes.

Filters are used to reduce the result set of a View to a manageable amount of data. They are a critical part of the foundation of this system. The filtering system is a compromise between flexibility and ease of use. To be truly powerful, filters should provide the ability to do an OR, but as it stands, these filters are all AND together. It means that every filter is applied. While the ability to do an OR would be nice, unfortunately the level of complexity in the interface to do that is well beyond the benefit that would be given. The order of filters is irrelevant, though they can be re-ordered as a convenience. Exposed filters are shown to the user, so that the result set can be modified. The typical example of this is to expose taxonomy as a filter so that the user can select which taxonomy term to filter on. The order of the exposed filters, controls the order in which they are presented to the user.

For amino acid sequences, it is possible to search in a FASTA sequence database, and through the latest views. Amino acid sequences can also be found within the database of L-amino acid oxidase (LAAO) (EC 1.4.3.2), Metalloproteinase - (MP) (EC 3.4.17), Phospholipase $A_{2}$ - $\left(P_{2} A_{2}\right)(E C$ 3.1.1.4) and Serine protease - (SP) (EC 3.4.21).

Scientific articles can be found in the Publications database; searching by authors, journal, journal and year and only by year. Yet, it is possible to see the latest viewed articles.

Besides all these possibilities of searching, there is an easy way to relate this information and find anything needed by mixing the available databases. As an example, it is possible to search for a plant with anti-hemolytic properties that can act against Bothrops asper venom.

The tags registered in a class of categories can be displayed in a symbolic form of cloud, sorted in alphabetical order and with different font sizes and dimensions, related to the number of items found on each term. The Tagadelic module offers various ways to add terms and vocabularies in one tag cloud. By using the Uniform Resource Locator (URLs), it is possible to create one specific cloud pages. It also offers a sideblock for each taxonomy tree.

Up to now, the amount of data registered in the system is: 68 plants, 43 species of venomous animals, 53 possibilities of anti-venom activity, 5905 scientific articles and 925 amino acid sequences. The data submitted can be viewed using the resources available in the system as: simple search by keywords, by listing names and terms of categories. All these data have been published and defined as public and will be listed in any type of search throughout the system.

\section{CONCLUDING REMARKS}

The Plant-antivenom system is available on the Internet at http://gbi.fmrp.usp.br/plantantivenom. It helps to develop the integration of data from medicinal plants and anti-venom activity, by providing different types of queries and views to the Internet user. In addition, it has a functionality as a whole system and its database, exercising the function of storing and making the rehabilitation and integration of these data more usual and intelligible, providing public data, allowing researchers / collaborators to 
Amui et al.

embed data from medicinal plants, contributing directly to the development, update of the database and to the advance in researches about medicinal plants with anti-venom properties.

\section{ACKNOWLEDGMENTS}

Authors would also like to thank Danilo L. Menaldo (FCFRP/USP) for his collaboration in the elaboration of this manuscript.

Financial support: Plant-antivenom is supported by Fundação de Amparo à Pesquisa do Estado de São Paulo (FAPESP), Conselho Nacional de Desenvolvimento Científico e Tecnológico (CNPq), and Coordenação de Aperfeiçoamento de Pessoal de Nível Superior (CAPES).

\section{REFERENCES}

ABUBAKAR, M.S.; SULE, M.I.; PATEH, U.U.; ABDURAHMAN, E.M.; HARUNA, A.K. and JAHUN, B.M. (2000). In vitro snake venom detoxifying action of the leaf extract of Guiera senegalensis. Journal of Ethnopharmacology, vol. 69, no. 3, p. 253-257. [CrossRef]

AGUIYI, J.C.; GUERRANTI, R.; PAGANI, R. and MARINELLO, E. (2001). Blood chemistry of rats pretreated with Mucuna pruriens seed aqueous extract MP101UJ after Echis carinatus venom challenge. Phytotherapy Research, vol. 15, no. 8, p. 712-714. [CrossRef]

BATINA, M.F.C.; CINTRA, A.C.O.; VERONESE, E.L.G.; LAVRADOR, M.A.S.; GIGLIO, J.R.; PEREIRA, P.S.; DIAS D.A.; FRANÇA S.C. and SAMPAIO, S.V. (2000). Inhibition of the lethal and myotoxic activities of Crotalus durissus terrificus venom by Tabernaemontana catharinensis: Identification of one of the active components. Planta Medica, vol. 66, no. 5, p. 424-428. [CrossRef]

BIONDO, R.; PEREIRA, A.M.; MARCUSSI, S.; PEREIRA, P.S.; FRANÇA, S.C. and SOARES, A.M. (2003). Inhibition of enzymatic and pharmacological activities of some snake venoms and toxins by Mandevilla velutina (Apocynaceae) aqueous extract. Biochimie, vol. 85, no. 10, p. 1017-1025. [CrossRef]

BIONDO, R.; SOARES, A.M.; BERTONI, B.W.; FRANÇA, S.C. and PEREIRA, A.M.S. (2004). Direct organogenesis of Mandevilla illustris (Vell) Woodson and effects of its aqueous extract on the enzymatic and toxic activities of Crotalus durissus terrificus snake venom. Plant Cell Reports, vol. 22, no. 8, p. 549-552. [CrossRef]

BORGES, M.H; SOARES, A.M.; RODRIGUES, V.M.; ANDRIÃO-ESCARSO, S.H.; DINIZ, H.; HAMAGUCHI, A.; QUINTERO, A.; LIZANO, S.; GUTIÉRREZ, J.M.; GIGLIO, J.R. and HOMSI-BRANDEBURGO, M.I. (2000). Effects of aqueous extract of Casearia sylvestris (Flacourtiaceae) on actions of snake and bee venoms and on activity of phospholipases $\mathrm{A}_{2}$. Comparative Biochemistry and Physiology Part B: Biochemistry and Molecular Biology, vol. 127, no. 1, p. 21-30. [CrossRef]

BORGES, M.H.; SOARES, A.M.; RODRIGUES, V.M.; OLIVEIRA, F.; FRANSHECHI, A.M.; RUCAVADO, A.; GIGLIO, J.R. and HOMSI-BRANDEBURGO, M.I. (2001). Neutralization of proteases from Bothrops snake venoms by the aqueous extract from Casearia sylvestris (Flacourtiaceae). Toxicon, vol. 39, no. 12, p. 18631869. [CrossRef]

CHIPPAUX, J.P. (1998). Snake-bites: Appraisal of the global situation. Bulletin of the World Health Organization, vol. 76, no. 5, p. 515-524.

CHIPPAUX, J.P. and GOYFFON, M. (2008). Epidemiology of scorpionism: A global appraisal. Acta Tropica, vol. 107, no. 2, p. 71-79. [CrossRef]

DA SILVA, J.O.; COPPEDE, J.S.; FERNANDES, V.C.; SANT'ANA, C.D.; TICLI, F.K.; MAZZI, M.V.; GIGLIO, J.R.; PEREIRA, P.S.; SOARES, A.M. and SAMPAIO, S.V. (2005). Antihemorrhagic, antinucleolytic and other antiophidian properties of the aqueous extract from Pentaclethra macroloba. Journal of Ethnopharmacology, vol. 100, no. 1-2, p. 145-152. [CrossRef]

DIOGO, L.C.; FERNANDES, R.S.; MARCUSSI, S.; MENALDO, D.L.; ROBERTO, P.G.; MATRANGULO, P.V.F.; PEREIRA, P.S.; FRANÇA, S.C.; GIULIATTI, S.; SOARES, A.M. and LOURENÇO, M.V. (2009). Inhibition of snake venoms and phospholipases $A_{2}$ by extracts from native and genetically modified Eclipta alba: Isolation of active coumestans. Basic \& Clinical Pharmacology \& Toxicology, vol. 104, no. 4, p. 293-299. [CrossRef]

FERREIRA, L.A.; HENRIQUES, O.B.; ANDREONI, A.A.S.; VITAL, G.R.F.; CAMPOS, M.M.C.; HABERMEHL, G.G and MORAES L.G.V. (1992). Antivenom and biological effects of ar-turmerone isolated from Curcuma longa (Zingiberaceae). Toxicon, vol. 30, no. 10, p. 1211-1218. [CrossRef]

HAVSTEEN, B. (1983). Flavonoids, a class of natural products of high pharmacological potency. Biochemical Pharmacology, vol. 32, no. 7, p. 1141-1148. [CrossRef]

JANUÁRIO, A.H.; SANTOS, S.L.; MARCUSSI, S.; MAZZI, M.V.; PIETRO, R.C.L.R.; SATO, D.N.; ELLENA, J.; SAMPAIO, S.V.; FRANÇA, S.C. and SOARES, A.M. (2004). Neo-clerodane diterpenoid, a new metalloprotease snake venom inhibitor from Baccharis trimera (Asteraceae): Anti-proteolytic and antihemorrhagic properties. Chemico-Biological Interactions, vol. 150, no. 3, p. 243-251. [CrossRef]

KASTURIRATNE, A.; WICKREMASINGHE, A.R.; SILVA, N.; GUNAWARDENA, N.K.; PATHMESWARAN, A.; PREMARATNA, R.; SAVIOLI, L.; LALLOO, D.G. and SILVA, H.J. (2008). The global burden of snakebite: A literature analysis and modelling based on regional estimates of envenoming and deaths. PLoS Medicine, vol. 5 , no. 11 , p. e218. 
MAHANTA, M. and MUKHERJEE, A.K. (2001). Neutralisation of lethality, myotoxicity and toxic enzymes of Naja kaouthia venom by Mimosa pudica root extracts. Journal of Ethnopharmacology, vol. 75, no. 1, p. 55-60. [CrossRef]

MAIORANO, V.A.; MARCUSSI, S.; DAHER, M.A.; OLIVEIRA, C.Z.; COUTO, L.B.; GOMES, O.A.; FRANÇA, S.C.; SOARES, A.M. and PEREIRA, P.S. (2005). Antiophidian properties of the aqueous extract of Mikania glomerata. Journal of Ethnopharmacology, vol. 102, no. 3, p. 364-370. [CrossRef]

MARTZ, W. (1992). Plant with a reputation against snakebite. Toxicon, vol. 30, no. 10, p. 1131-1142. [CrossRef]

MORS, W.B.; NASCIMENTO, M.C.; PEREIRA, B.M.R. and PEREIRA, N.A. (2000). Plant natural products active against snake bite - the molecular approach. Phytochemistry, vol. 55, no. 6, p. 627-642.

OLIVEIRA, C.Z.; MAIORANO, V.A.; MARCUSSI, S.; SANT'ANA, C.D.; JANUÁRIO, A.H.; LOURENÇO, M.V.; SAMPAIO, S.V.; FRANÇA, S.C.; PEREIRA, P.S. and SOARES, A.M. (2005). Anticoagulant and antifibrinogenolytic properties of the aqueous extract from Bauhinia forficata against snake venoms. Journal of Ethnopharmacology, vol. 98, no. 1-2, p. 213-216. [CrossRef]

OTERO, R.; NUÑEZ, V.; BARONA, J.; FONNEGRA, R.; JIMENEZ, S.L.; OSORIO, R.G.; SALDARRIAGA, M. and DIAZ, A. (2000). Snakebites and ethnobotany in the northwest region of Colombia: Part III: Neutralization of the haemorrhagic effect of Bothrops atrox venom. Journal of Ethnopharmacology, vol. 73, no. 1-2, p. 233241. [CrossRef]

SELVANAYAGAM, Z.E.; GNANAVENDHAN, S.G.; BALAKRISHNA K.; RAO, R.B.; SIVARAMAN, J.; SUBRAMANIAN, K.; PURI, R. and PURI, R.K. (1996). Ehretianone, a novel quinonoid xanthene from Ehretia buxifolia with antisnake venom activity. Journal of Natural Products, vol. 59, no. 7, p. 664-667. [CrossRef]

SOARES, A.M.; JANUÁRIO, A.H.; LOURENÇO, M.V.; PEREIRA, A.M. and PEREIRA, P.S. (2004). Neutralizing effects of Brazilian plants against snake venoms. Drugs of the Future, vol. 29, no. 11, p. 1105-1117. [CrossRef]

SOARES, A.M.; TICLI, F.K.; MARCUSSI, S.; LOURENÇO, M.V.; JANUÁRIO, A.H.; SAMPAIO, S.V.; GIGLIO, J.R.; LOMONTE, B. and PEREIRA, P.S. (2005). Medicinal plants with inhibitory properties against snake venoms. Current Medicinal Chemistry, vol. 12, no. 22, p. 2625-2641. [CrossRef]

SOARES, A.M.; MARCUSSI, S.; FERNANDES, R.S.; MENALDO, D.L.; COST, T.R.; LOURENÇO, A.H.J. and PEREIRA, P.S. (2009). Medicinal plant extracts and molecules as the source of new anti-snake venom drugs. In: RAHMAN, A.; REITZ, A.B. and CHOUDHARY, M.I. eds. Karachi-Pakistan: Bentham Science Publishers. Frontiers in Medicinal Chemistry, vol. 4, p. 309-346.

TICLI, F.K.; HAGE, L.I.; CAMBRAIA, R.S.; PEREIRA, P.S.; MAGRO, A.J.; FONTES, M.R.; STÁBELI, R.G.; GIGLIO, J.R.; FRANÇA, S.C.; SOARES, A.M. and SAMPAIO, S.V. (2005). Rosmarinic acid, a new snake venom phospholipase $\mathrm{A}_{2}$ inhibitor from Cordia verbenacea (Boraginaceae): Antiserum action potentiation and molecular interaction. Toxicon, vol. 46, no. 3, p. 318-327. [CrossRef]

\section{How to cite this article:}

AMUI, S.-F.; PUGA, R.D.; SOARES, A.M. and GIULIATTI, S. (2011). Plant-antivenom: Database of anti-venom medicinal plants. Electronic Journal of Biotechnology, vol. 14, no. 1. http://dx.doi.org/10.2225/vol14-issue1fulltext-1 